\title{
The Appearance of Justice and the Bottom Line Defense
}

\author{
Eric Lasker
}

In Connecticut v. Teal, ${ }^{1}$ the United States Supreme Court rejected the bottom line defense in an employment discrimination case brought under title VII. ${ }^{2}$ This defense, previously accepted by a majority of the Federal courts that had addressed the issue ${ }^{3}$ and included in the 1978 Uniform Guidelines on Employment Selection Procedure (U.G.E.S.P.), ${ }^{4}$ allowed an employer to utilize a selection procedure that had a disproportionate impact on protected groups if the employer compensated for that impact elsewhere in its selection process. In rejecting the bottom line argument, the Supreme Court held that title VII prohibited any procedures that imposed "barriers" and "deprive[d] . . any individual of employment opportunities." According to Teal, individuals excluded from a selection process because of a test with a disparate impact ${ }^{6}$ were entitled to protection under title VII regardless of any subsequent remedial actions taken by the employer to ensure that there was no ultimate disparate impact in the selection process as a whole.

The Supreme Court's opinion, however, did not clearly preclude all use of the bottom line defense. In his dissent in Teal, Justice Powell suggested that under the Court's ruling a multicomponent employment process, ${ }^{7}$ in which a variety of measures were used collectively for selection with no single factor or sub-test constituting a pass-fail barrier beyond which an applicant could not compete further, would still be protected by the bot-

1. 457 U.S. 440 (1982).

2. 42 U.S.C. $\$ 2000 \mathrm{e}(1982)$

3. See Smith v. Troyan, 520 F.2d 492 (6th Cir. 1975), cert. denied, 426 U.S. 934 (1976); Kirkland v. New York State Dep't of Correctional Servs., 520 F.2d 420 (2d Cir. 1975); Brown v. New Haven Civil Serv. Bd., 474 F. Supp. 1256 (D. Conn. 1979). But see Johnson v. Goodyear Tire and Rubber Co., 491 F.2d 1364 (5th Cir. 1974); EEOC v. Trailways, Inc., 530 F. Supp. 54 (D. Colo. 1081). The type of bottom line defense rejected in these latter two cases, however, differed from that described in this Note in that it focused on the percentage of minorities in the general population as opposed to the percentage in the applicant class.

4. 29 C.F.R. $\$ 1607.4$ (c) (1988). These regulations remain in force despite the Supreme Court's decision in Teal.

5. 457 U.S. at 448 (emphasis in original).

6. For a discussion of the disparate impact standard, see infra text accompanying note 11 .

7. Multicomponent procedures generally rely on a number of different selection standards that may be based on merit, diversity, equity, or other concerns. These procedures are termed universalistic, while pass-fail tests, due to their emphasis on a particular standard, are termed particularistic. A bottom line defense could be invoked for a multicomponent procedure when one of the selection standards has a disparate impact, but the procedure as a whole does not. 
tom line defense. ${ }^{8}$ Subsequent to Teal, the Federal circuits have split on the question of the use of the bottom line defense by employers utilizing multicomponent selection procedures. ${ }^{\theta}$

This Note argues that the holding in Teal should not govern multicomponent processes. Although a multicomponent process, like a pass-fail test, may ultimately lead to the rejection of an individual job applicant due to a standard that has a disparate impact on minority or female applicants, ${ }^{10}$ such a standard will not foster the same perceptions of unfair process and racial or sexual inequality that are fostered by a pass-fail test. These perceptions impose barriers to job opportunities for minority and female job candidates, thus contradicting the purposes behind title VII which the Court sought to protect in Teal.

Section I of this Note provides background on the bottom line defense and on the Supreme Court's ruling in Teal. Section II describes the split that has developed in the circuits since Teal and examines the opposing arguments. Section III offers a new perspective on the bottom line controversy by examining the divergent effects of pass-fail barriers and multicomponent techniques on public perceptions of racial and sexual equality. Finally, Section IV argues that the conflict over the bottom line defense should be resolved by giving legal weight to the effect of pass-fail barriers and multicomponent techniques on public perceptions of racial or sexual equality, since these perceptions are intimately related to the ultimate achievement of equal opportunity.

\section{Background on the Bottom Line Defense and Teal}

Eleven years prior to Teal, the Supreme Court, in Griggs v. Duke Power Co. ${ }^{11}$ established the disparate impact test for liability under title VII. This test outlawed facially neutral employee selection practices that resulted in the hiring or promotion of disproportionately fewer minority or female candidates unless the selection practice was shown to be jobrelated. Following Griggs, employers began to revise their employment practices in order to satisfy the new legal standard. In attempting to continue "merit" selection, many employers combined standardized tests or other selection procedures that had a disparate impact on minority candi-

\section{Powell reasoned:}

Another possibility is that employers may integrate consideration of test results into one overall

hiring decision based on that "factor" and additional factors. Such a process would not, even under the Court's reasoning, result in a finding of discrimination on the basis of disparate impact unless the actual hiring decisions had a disparate impact on the minority group.

457 U.S. at 463 n.8 (Powell, J., dissenting) (emphasis in original).

9. See infra notes 30-32.

10. See Chamallas, Evolving Conceptions of Equality Under Title VII: Disparate Impact Theory and the Demise of the Bottom Line Principle, 31 UCLA L. REv. 305, 359 (1983); Scanlan, The Bottom Line Limitation to the Rule of Griggs v. Duke Power Company, 18 U. Mich. J.L. Ref. 705, 737 (1985).

11. 401 U.S. 424 (1971). 
dates with race- or sex-based affirmative action programs. ${ }^{12}$ Although this approach often excluded a higher percentage of minorities or women at a preliminary stage of the selection process, the percentage of applicants in these groups selected from the resulting pool of "qualified" applicants was greater than that of white males. Thus, at the end of the selection process, the "bottom line," minority and female applicants were accepted at a rate at least equal to that of white male applicants. Because no disparate impact appeared after the final stage of the employment process, employers argued that they need not prove the job-relatedness of the challenged selection standard which by itself had a disparate impact. ${ }^{13}$

During the decade between Griggs and Teal, the Supreme Court, while not directly ruling on the bottom line defense, began to lay a foundation for its use. In a series of cases, the Court rejected title VII claims by relying, at least in part, on evidence that the end result of the employers' selection processes showed that an adequate percentage of minority applicants had been hired. ${ }^{14}$ The decision in United Steelworkers $v$. Weber ${ }^{15}$ further supported the possibility of the bottom line defense. In Weber, the Court reviewed an employer's affirmative action plan which was being challenged by qualified, yet unsuccessful, white job applicants. The plan at issue in Weber was similar to those often used in bottom line approaches to compensate for the disparate impact of intermediate testing procedures. A ruling that such a remedial plan constituted improper reverse discrimination would have severely limited the availability of the bottom line approach. The Court, however, upheld the plan, affirming the potential availability of this critical feature of the bottom line strategy.

While the Supreme Court was lending indirect support to the bottom line principle, lower Federal courts were directly rejecting claims brought

12. See Blumrosen, The Bottom Line Concept in Equal Employment Opportunity Law, 12 N.C. Cent. L.J. 1, 3-4 (1980).

13. This past Term, in Wards Cove Packing Co. v. Atonio, 109 S. Ct. 2115 (1989), the Supreme Court shifted the burden of proof in cases in which a disparate impact is found. Although employers still have the burden of production in showing that a challenged selection process with disparate impact is job-related, plaintiffs now bear the ultimate burden of persuasion to prove that the process is not job-related. Thus, an employer who unsuccessfully asserts the bottom line defense no longer has the burden of proving that the challenged procedure was job-related. The employer must still, however, defeat the plaintiffs initial showing that the procedure was not job-related, a burden that would not be present if the bottom line defense were successful.

This argument does not reach cases of discriminatory intent. Evidence of discriminatory intent at any stage could be sufficient to prove a title VII violation. $C f$. Village of Arlington Heights v. Metropolitan Hous. Dev. Corp., 429 U.S. 252, 270 n.21 (1977) (evidence of discriminatory purpose shifts burden to defendants to prove action would have been taken absent such purpose).

14. See New York City v. Beazer, 440 U.S. 568, 584 n.25 (1979) (title VII claim defeated where employer hired minority workers at rate double that found in work force at large); Washington v. Davis, 426 U.S. 229, 235-36 (1976) (employer's overall recruitment and hiring of minorities led to relaxation of EEOC standards for testing); Espinoza v. Farah Mfg. Co., 414 U.S. 86, 86 (1973) (Court rejected Mexican-American's employment discrimination claim based on finding that $90 \%$ of employees were Mexican-Americans); see also Blumrosen, supra note 12, at 6-11 (discussing abovecited cases as supporting bottom line defense).

15. 443 U.S. 193 (1979). 
by black applicants against bottom line selection procedures. ${ }^{16}$ In Smith $v$. Troyan, ${ }^{17}$ for example, the Sixth Circuit rejected a disparate impact claim brought by black police applicants by relying on the equal selection rates at the bottom line. The court reasoned:

That blacks fare less well than whites on the AGCT, a "subtest" in the process of hiring East Cleveland police officers, is insufficient in itself to require defendants to justify the AGCT as being job-related. Carried to its logical extreme, such a criterion would require the elimination of individual questions marked by poorer performance by a racial group, on the ground that such a question was a "subtest" of a "subtest."18

Against this backdrop, Winnie Teal and three other black state employees sued the Department of Income Maintenance of the State of Connecticut for using an examination with a disparate impact as part of its promotion process. $^{19}$ Candidates who failed the Department's written examination were excluded from further consideration for promotion. Approximately one month before the case came to trial, the defendants made their first promotions from the eligibility list. The promotion decisions resulted in a higher percentage of blacks from the original applicant pool being promoted $(23 \%)$ than whites $(13.5 \%){ }^{20}$

The district court accepted the Department's bottom line defense and dismissed the action for failure to prove a prima facie case. ${ }^{21}$ On appeal, however, the Second Circuit reversed. Although upholding the reasoning in Troyan with regard to subtests within a selection process, the court held, "Where . . . an identifiable pass-fail barrier denies an employment opportunity to a disproportionately large number of minorities and prevents them from proceeding to the next step in the selection process, a different result must obtain." 22

The Second Circuit distinguished Troyan on the grounds that a passfail barrier, unlike the multicomponent selection procedure at issue in Troyan, would not require the court to "examine each component of an entire application process . . . on a course that has no boundaries and no

16. See supra note 3 and accompanying text.

17. 520 F.2d 492 (6th Cir. 1975), cert. denied, 426 U.S. 934 (1976).

18. Id. at 498 . It is important to note that the bottom line defense presupposes that the selection criteria have not been shown to be job-related.

19. The written examination, which was not shown to be job-related, had resulted in a passing rate of $54.17 \%$ for blacks, approximately $68 \%$ of the rate at which white applicants passed (79.53\%). Teal v. Connecticut, 645 F.2d 133, 136 (2d Cir. 1981), affd, 457 U.S. 440 (1982).

20. Id.

21. Id. at 134 (district court opinion unpublished); $c f$. Albemarle Paper Co. v. Moody, 422 U.S. 405,425 (1975) (prima facie case proved if tests in question select applicants for hire or promotion in racial pattern significantly different from that of pool of applicants).

22. Teal, 645 F.2d at 138 (emphasis added). 
clear end."23 The court reasoned, "In the case of a pass-fail barrier, both the discriminatory component and the affected individuals are readily identifiable. Courts are under an obligation to entertain the claims of individuals who have been victimized by a discriminatory pass-fail barrier, notwithstanding any belated 'corrective' action taken by the employer."24

The United States Supreme Court affirmed the Second Circuit's holding. ${ }^{28}$ The Court did not address the distinction raised by the Second Circuit between pass-fail barriers and multicomponent processes, however. Instead, the Court focused on the language of section 703(a)(2) of title VII, which the Court had previously found to prohibit "artificial, arbitrary, and unnecessary barriers to employment [that] . . limit . . . or classify ... a applicants for employment . . . in any way which would deprive or tend to deprive any individual of employment opportunities."26 The Court held that the test employed by the Connecticut Department of Income Maintenance constituted such a barrier. The Court found that the purpose of title VII was to protect individuals, ${ }^{27}$ and held, therefore, that the ultimate promotion of other minority applicants did not negate the plaintiffs' claim. In the closing passages of its opinion, the Court focused on the underlying purposes of title VII which were violated in the case: "Requirements and tests that have a discriminatory impact are merely some of the more subtle, but also the more pervasive, of the 'practices and devices which have fostered racially stratified job environments to the disadvantage of minority citizens." "28

By resting its decision on "barriers" to individuals' "employment opportunities," and by failing to address the distinction raised by the Second Circuit between pass-fail barriers and multicomponent selection processes, the Court left the door open for employers to assert that multicomponent approaches were not covered by the Teal decision. ${ }^{29}$ Moreover, as will be discussed in Section IV, the Court's concern with preventing selection procedures which "foster[] racially stratified job environments" lends support to the argument that its holding was primarily intended to prohibit the use of the bottom line defense in the case of pass-fail tests.

\section{The Split in the Gircuits}

In the years following Teal, the circuits have divided on the question of whether the bottom line defense applies to multicomponent selection techniques. Courts in the Second and Sixth Circuits support the use of the

23. Id. (citing Brown v. New Haven Civil Serv. Bd., 474 F. Supp. 1256, 1262 (D. Conn. 1979)).

24. Id. at 139 .

25. Connecticut v. Teal, 457 U.S. 440 (1982).

26. Id. at 448 (quoting Griggs v. Duke Power Co., 401 U.S. 424, 431 (1971) (emphasis in original)).

27. Id. at 455 .

28. Id. at 456 (quoting McDonnell Douglas Corp. v. Green, 411 U.S. 792, 800 (1973)).

29. See supra note 8 and accompanying text. 
bottom line defense in the context of multicomponent tests. ${ }^{30}$ Courts in the Fifth, Seventh, and Eighth Circuits, while not explicitly addressing multicomponent procedures, have used language in rejecting bottom line defenses that appears to limit their holdings to pass-fail barriers. ${ }^{31}$ The First and Third Circuits, on the other hand, have rejected the bottom line defense in cases involving multicomponent selection processes. ${ }^{32}$ The Supreme Court has not indicated a willingness to resolve this split in the circuits. In May 1988, the Court avoided confronting this issue by denying certiorari in Brunet $v$. City of Columbus, ${ }^{33}$ a case in which the bottom line defense was upheld for a multicomponent selection process.

\section{A. Arguments in Favor of the Bottom Line Defense}

Courts and legal scholars who accept the bottom line defense for multicomponent processes focus on the concept of "barriers" to employment opportunities. ${ }^{34}$ They argue that a multicomponent approach does not impose barriers to employment opportunities because every applicant is given the opportunity to compete at every stage of the employment decision, regardless of a poor showing at any one level. Thus, an individual applicant is given an opportunity to compensate for an inadequate showing at one stage of the process by scoring high at a later stage.

This argument, which limits the interpretation of "barriers" to pass-fail tests, provided the basis for the Southern District of Ohio's holding in Brunet. In Brunet, several female firefighter applicants brought suit against the Columbus Fire Department alleging that two components of the firefighter examination, the physical test and the mechanical reasoning test, had a disparate impact on female applicants. Neither of these components constituted a pass-fail barrier; rather, they were each weighted factors in the overall scoring of the examination, which, taken as a whole, did not have a disparate impact. In finding for the City of Columbus, the district court distinguished the Supreme Court's ruling in Teal, arguing that Teal only reached those procedures that constituted pass-fail barriers: "[T]he written examination in Teal constituted a 'barrier' in the sense

30. See Connecticut v. Teal, 645 F.2d 133, 138-39 (2d Cir. 1981), affd, 457 U.S. 440 (1982); Brunet v. City of Columbus, 642 F. Supp. 1214, 1224-26 (S.D. Ohio 1986), appeal dismissed, 826 F.2d 1062 (6th Cir. 1987), cert. denied, 108 S. Gt. 1593 (1988).

31. See Carpenter v. Stephen F. Austin State Univ., 706 F.2d 608, 622 (5th Cir. 1983); Leftwich v. Harris-Stowe State College, 702 F.2d 686, 691 (8th Cir. 1983); Schutz v. Western Publishing Co., 609 F. Supp. 888, 904 (N.D. Ill. 1985).

32. See Wilmore v. City of Wilmington, 699 F.2d 667, 672-73 (3d Cir. 1983); Burney v. City of Pawtucket, 559 F. Supp. 1089, 1098-1100 (D.R.I. 1983), appeal dismissed, 728 F.2d 547 (1st Cir. 1984).

33. 642 F. Supp. 1214 (S.D. Ohio 1986), appeal dismissed, 826 F.2d 1062 (1987), cert. denied, 108 S. Ct. 1593 (1988).

34. See supra note 30; see also Note, The Bottom Line Concept in Title VII Litigation: Connecticut v. Teal and the Relevance of End Results, 15 CoNN. L. REv. 821 (1983) (arguing in favor of bottom line defense). 
that it precluded candidates from further consideration. The challenged components of the testing process here, even though lower scores on these components may lessen a candidate's overall chance of acceptance, do not preclude further consideration of that candidate."38 The argument in Brunet borrowed much of its reasoning from the Second Circuit's holding in Teal, which remains valid precedent in that circuit. ${ }^{36}$

\section{B. Arguments Opposing the Bottom Line Defense}

Courts and legal scholars opposing the view articulated in Brunet ${ }^{37}$ argue that a distinction based on employment "barriers" is untenable. An individual who scores poorly at one stage of a multicomponent testing scheme still faces a barrier to employment opportunity. Even though the applicant is allowed to continue through the entire employment decisionmaking process, his or her chances of selection are decreased, perhaps significantly. Thus, according to these commentators, no analytical justification exists for distinguishing between pass-fail barriers and components in a multicomponent process when both, in fact, act as barriers to an individual applicant's employment opportunities.

This argument provides the basis for the District of Rhode Island's rejection of the bottom line defense in Burney $v$. City of Pawtucket, ${ }^{38}$ a case which arose out of a fact pattern similar to that of Brunet. In Burney, a female police cadet brought suit against the Rhode Island Municipal Police Academy for its use of a physical training program and the Post Physical Performance Test (POST-Test), both of which had a disproportionate impact on female cadets. The defendants argued that a finding of disparate impact would be erroneous because all of the women who had entered the Academy since the institution of the POST-Test had graduated, ${ }^{39}$ and despite having received lower scores on the POST-Test, twothirds of the female graduates had finished in the top half of their class. ${ }^{40}$ The court rejected this defense, holding that '[s]uch 'bottom line' justifications had been flatly rejected by the Supreme Court in Connecticut $v$. Teal . ..."1 While noting that Teal had concerned a pass-fail barrier, the court held that " $[t]$ he teachings of Teal ... are that the end, no matter how pristine, cannot in the context of Title VII justify tainted means.

35. Brunet, 642 F. Supp. at 1225.

36. Cf. United States v. City of Yonkers, 592 F. Supp. 570, 589-90 (S.D.N.Y. 1984) (citing Second Circuit's Teal decision as reaching pass-fail barriers).

37. See supra notes 10 \& 32 .

38. 559 F. Supp. 1089, 1098-1100 (D.R.I. 1983), appeal dismissed, 728 F.2d 547 (1st Cir. 1984).

39. The plaintiff in this case was apparently the first female cadet to be asked to leave the Academy as a result of the physical training requirements.

40. Burney, 559 F. Supp. at 1099 \& n.16.

41. Id. at 1099 . 
Defendants' 'bottom line' argument is conceptually indistinguishable from the assertions rejected in Teal . . .".42

The Third Circuit adopted a similar position in Wilmore v. City of Wilmington. ${ }^{43}$ In that case a fire department had deprived minority firefighters of the on-the-job experience that contributed to improved scores on a promotion examination. 4 The fire department relied on the bottom line defense, arguing that the minority firefighters had not fared significantly worse on the examination than white firefighters. ${ }^{45}$ The court, relying on Teal, rejected this defense.

\section{The Impact of Public Perceptions of Employment Procedures}

The debate over the potential future vitality of the bottom line defense has centered on the courts' varying conceptions of what constitutes a barrier to employment opportunity. In an effort to establish a clear standard for future applications of Teal, the courts have been deciding multicomponent process, bottom line defense cases based on one of two polar definitions: that a barrier is anything that could possibly hinder an individual's job opportunity ${ }^{48}$ or that a barrier is only something which absolutely forecloses a job opportunity. ${ }^{47}$ As such, the reasoning of the two sides seems irreconcilable. This section, however, proposes a new standard by which the courts can judge the bottom line defense: the degree to which employment selection procedures affect public perceptions of racial or sexual equality and the consequential impact of these perceptions on equal opportunity for job applicants. It is the position of this Note that such an analysis provides a more reasoned approach for adjudication of future bottom line defense cases than does either of the two polar positions thus far adopted by the courts.

\section{Id. at 1100 .}

43. 699 F.2d 667 (3d Cir. 1983).

44. The district court had found evidence of purposeful racial discrimination on the part of the fire department in depriving the minority firefighters of this experience. Id. at 671. This finding may have influenced the court in its decision to recognize a disparate impact claim by minority firefighters, despite the bottom line equality of the process.

45. Minorities had actually performed better than whites on the promotional exam. Id. at 674 .

46. See Burney, 559 F. Supp. at 1100 (rejecting defendant's claim that effect of disparate impact of subtest was de minimus).

47. See Brunet v. City of Columbus, 642 F. Supp. 1214, 1226 (S.D. Ohio 1986), appeal dismissed, 826 F.2d 1062 (6th Cir. 1987), cert. denied, 108 S. Ct. 1593 (1988) (court holds that critical premise of Teal was that challenged standard "eliminated individuals from further consideration"). The Brunet court, it should be noted, directly rejected the reasoning of the court in Burney. Id. at 1228-29. 


\section{A. The Role of Perceptions in Discrimination}

In his book, White Racism: A Psychohistory, ${ }_{2}^{48}$ Joel Kovel argues that prejudice is in large part maintained and perpetuated through symbols that encourage the public to perceive inaccurate distinctions between the races or sexes. ${ }^{49}$ Henri Tajfel, Professor of Social Psychology at the University of Bristol, has described the social phenomenon whereby the effects of past discrimination provide fuel for future discrimination:

We are then confronted with a spiral effect in which the existence of prejudice at large not only provides additional support and rewards for hostile judgments; it also removes the possibility of a 'reality check' for these judgements which then feed upon each other and become more and more strongly entrenched in the form of powerful social myths. ${ }^{\text {so }}$

Tajfel maintains that attacking these perceptions of group inequality, although difficult, is the easiest way to break out of this cycle:

It is patently obvious that . . . beliefs and views about causes of social events which are held by great masses of men are more easily accessible to change than their motives; and that there is at least a chance that a change of beliefs and views may affect in turn the management of conflicts, real or imaginary. ${ }^{51}$

Tajfel's analysis suggests a useful starting point for considering the impact of the different hiring procedures considered in this Note.

\section{B. The Impact of Hiring Procedures on Perceptions of Equality}

While title VII doctrine has focused primarily on the end result of employment decisions, social scientists recently have become interested in the impact of the selection procedures themselves on public perceptions. ${ }^{52}$ Jeffrey Prager asserts that the failure to obtain public acceptance for affirmative action programs has resulted primarily from the failure of society to recognize or to address the impact of procedures such as pass-fail barriers on the public psyche:

48. J. Kovel, White Racism: A Psychohistory (1970).

49. Indeed, Kovel argues that "culture itself is established to maintain the world in a shape that conforms to the symbolic needs of the ego's activity." Id. at 99. "If such an infantile response [prejudice] can maintain such intensity in the most mature and 'normal' of adults," Kovel reasons, "then there must be something at large in culture [i.e., symbols] to sustain it." Id. at 93-94.

50. Tajfel, The Roots of Prejudice: Cognitive Aspects, in PsYchology and RACE 76, 85 (P. Watson ed. 1973).

51. Id. at 93-94; see also J. KoveL, supra note 48, at 99-100 (discussing importance of symbolic restructuring as means of altering real world).

52. See Greenberg \& Folger, Procedural Justice, Participation, and the Fair Process Effect in Groups and Organizations, in BAsIC Group Processes 235 (P.B. Paulus ed. 1985) (distinguishing between distributive and procedural justice in employer decision-making). 
In responding to a pressing social problem, [employers] forgo those procedures necessary to secure a continued legitimacy on behalf of the public; they ignore the danger of being popularly viewed as subjective, arbitrary and capricious. . . . In failing to assert a rationale for measuring probable success or a standard of success that is applied equally to all individuals, these institutional elites are helping insure that programs of affirmative action will fail to command broad-based popular support. ${ }^{\text {s3 }}$

In a companion piece, W. R. Newell considers the perceived consistency of different selection procedures with the meritocratic liberal tradition that underpins American culture. Newell argues that employers need to find selective procedures that are

flexible enough to stretch the liberal understanding of merit to respond to a pressing social problem without abandoning the traditional liberal reluctance to grant groups or races the same status in principle as individuals. The difference between the acceptance of "diversity" and the acceptance of a racial quota may seem like a small one, but it is the difference between a conception of public justice compatible with liberalism and one that is not. ${ }^{54}$

Pass-fail approaches in bottom line cases separate the selection decision into a "qualifications" phase and an "affirmative action" phase, leading to improper public perceptions at two stages. First, the pass-fail "qualification" standard leads to a disparate impact that demonstrably favors white males, promoting the perception that white males are, in some objective sense, more qualified than other groups. ${ }^{55}$ Next, the employer applies a race- or sex-based affirmative action program to assure placement of sufficient numbers of minorities or women from the class of "qualified" applicants. Since such particularistic selection techniques are perceived as arbitrary, ${ }^{56}$ minority and female applicants selected through such procedures

53. Prager, Merit and Qualifications: Contested Social Meanings and Their Impact on Affirmative Action, in Afrirmative Action: Theory, Analysis, and Prospects 21, 40 (M. Combs \& J. Gruhl eds. 1986).

54. Newell, Affirmative Action and the Dilemmas of Liberalism, in id. at 44, 58 .

55. See Lawrence, The Id, the Ego, and Equal Protection: Reckoning with Unconscious Racism, 39 STAN. L. REv. 317, 373 (1987). This effect does not require a public announcement of the test results. Many barriers, such as height and weight requirements, obviously favor the majority group (here, males). Others, such as standardized examinations, are currently known to favor whites, see Butler-Omololu, Doster \& Lahey, Some Implications for Intelligence Test Construction and Administration with Children of Different Racial Groups, $10 \mathrm{~J}$. BLACK Psycholocy 63, 65 (1984), because of either cultural-bias, see id. at 64-65, or actual skill differences in the measured areas, see Cronshaw, The Status of Employment Testing in Canada: A Review and Evaluation of Theory and Professional Practice, 27 Canadian Psychology 183 (1986). Where such standards are put forward as being central to one's qualification for a job, they are seen as proof of white male superiority. This perception is all the more dangerous given the fact that employers protected by the bottom line defense need not even show that the quality standard which has a disparate impact is, in fact, related to job performance.

56. See infra text accompanying notes $62 \& 64-65$. 
are often viewed as not deserving their position, both by themselves and by white male applicants who have been passed over. ${ }^{57}$ The selection of minority and female applicants is often perceived as charity to an "underskilled" group.

The perceptions that emerge from the use of pass-fail procedures are likely to lead to barriers to future job opportunities for minorities and women. Faced with the option of either being rejected through a "qualification" standard which has a disparate impact and has not even been shown to be job-related, or having their selection seen as charity, studies show that minority and female candidates may be less likely to apply for a job. ${ }^{88}$ Those minority and female applicants who do apply and are accepted, moreover, find their future job advancement opportunities continually impaired by the perception that they somehow did not merit the job in the first place. ${ }^{59}$

A series of studies conducted over the past few years has examined the impact of selection procedures on views regarding the fairness of affirmative action. ${ }^{80}$ These studies have found that women who were told that qualifications played a role in the selection of a female applicant (i.e., that the decision-making was universalistic or multicomponent) felt the decision to be a fair one to a significantly higher degree than did women told that the decision was strictly based on sex, even where both groups were told that the female possessed superior qualifications to the man ${ }^{61}$ Fur-

57. One might argue that this Note ignores the fact that the applicants had proved that they were qualified by passing the "qualification" standard. This argument relies on the assumption that the test is seen as sufficient, rather than necessary, evidence of skill. More fundamentally, however, studies show that people view race- or sex-based criteria as unfair even where the beneficiary is clearly objectively qualified. See infra text accompanying notes 60-70.

58. See infra note 63 and accompanying text.

59. Cf. Murray, Affirmative Racism: How Preferential Treatment Works Against Blacks, New REPUBLIC, Dec. 31, 1984, at 18 (describing lack of respect often accorded to beneficiaries of racebased affirmative action).

60. Rupert Nacoste, now an Associate Professor of Psychology at North Carolina State University, introduced a group of approximately 100 women to a role-playing situation in which a female professor was selected over a male professor for a research grant. Half of the women were told that the selection was ultimately based on sex; the other half were told that sex was considered only in combination with qualifications. See Nacoste, But Do They Care About Fairness? The Dynamics of Preferential Treatment and Minority Interest, 8 BAsic \& APPLIED Soc. Psycholocy 177 (1987) [hereinafter Nacoste, But Do They Care?]; Nacoste \& Lehman, Procedural Stigma, 17 RePresenTaTIVE Res. IN SOC. Psychology 25 (1987); Nacoste, Selection Procedure and Responses to Affirmative Action: The Case of Favorable Treatment, 9 LAw \& Hum. BeHav. 225 (1985) [hereinafter Nacoste, Selection Procedure]. The results of these studies were summarized in Nacoste, Social Psychology and Affirmative Action: The Importance of Process in Policy Analysis, $43 \mathrm{~J}$. Soc. IsSues 127 (1987) [hereinafter Nacoste, Social Psychology]; see also Tougas \& Veilleux, The Influence of Identification, Collective Relative Deprivation, and Procedure of Implementation on Women's Response to Affirmative Action: A Causal Modeling Approach, 20 Canadian J. Behav. Scr./Rev. Can. Sci. CoMP. 15 (1988) (similar study on psychological impact of selection procedures on women).

61. See Nacoste, Selection Procedure, supra note 60 , at 234 . The two groups of women in this study were faced with a situation that approximates that faced by women hired following multicomponent or pass-fail selection procedures respectively. In the study, as in the real life situation, both groups of women demonstrated the qualifications necessary to succeed at the given job. Women in one of the study groups, however, were told that their ultimate selection was based solely on their gender. These women were thus placed in a similar situation to women in the real world who are ultimately 
ther, women told that the decision was sex-based had less favorable views of the agency that made the selection decision and were, thus, less attracted to the agency. ${ }^{62}$ This finding lends empirical support to the argument made above that particularistic, as opposed to universalistic, procedures create barriers to job opportunities by fostering an environment in which minority and female candidates are less likely to apply for positions. $^{63}$

Men who are denied employment through these procedures also viewed the solely sex-based selection of women as being less fair than more universal selection decisions. ${ }^{84}$ One could plausibly expect, therefore, that minority or female workers selected through such a particularistic process would receive less respect in the workplace. ${ }^{65}$ This lack of respect imposes a serious additional hurdle to job advancement for these individuals, a hurdle that is not present to the same degree for minority or female applicants selected through a universalistic procedure.

A more sophisticated study has examined the effect of the selection procedure on beneficiaries' feelings of self-worth and belief in their own abilities. ${ }^{66}$ This study found that the purported procedure of selection had a strong impact on the perceptions of the female leaders:

These results provide strong evidence that sex-based preferential selection procedures can have detrimental effects on leaders' selfperceptions and self-evaluations, and that these detrimental effects occur despite information about performance quality. When selected

selected (over qualified white males) through an affirmative action program that follows a pass-fail qualifications barrier with disparate impact.

62. See Nacoste \& Lehman, supra note 60 , at 26-27 (individuals evaluate fairness of controlling agency and agency's view of individual on basis of fairness of selection procedure); Nacoste, But Do They Care?, supra note 60, at 185 (participants in universalistic procedure inferred that agency was "more committed to fairness").

63. See Nacoste, But Do They Care?, supra note 60, at 185 (study found that "[t]he universalistic condition led to greater willingness to apply . . . for a position with the agency than did the particularistic condition").

64. See Nacoste, Social Psychology, supra note 60, at 130. Researchers have argued that this reaction can also be found among nonbeneficiary whites, where a solely race-based decision-making process is used. See Kluegel, "If There Isn't a Problem, You Don't Need a Solution," 28 Am. Benav. ScI. 761, 776 (1985) (whites "will show a strong preference" for universalistic procedures, which measure each applicant as an individual, over particularistic procedures).

65. See Murray, supra note 59 (discussing lack of respect shown to minority beneficiaries of affirmative action).

66. Heilman, Simon \& Repper, Intentionally Favored, Unintentionally Harmed? Impact of SexBased Preferential Selection on Self Perceptions and Self-Evaluations, 72 J. APPLIED PsYchology 62 (1987). In this study, a group of women took part in what they were told was a research project in which they were to work with one other person (who was in fact a confederate posing as a male student). Before the project began, the two workers were asked to complete an examination which was then supposedly graded. Half of the women students were then told that they had scored higher than their fellow participant and therefore would lead in the carrying out of the research project. The other half were told that they had scored lower on the examination but were being chosen to lead anyway because not enough women had signed up for the project. The participants then carried out the task and were told how successful they had been in completing the task as compared to the rest of the pairs. Id. at 63-64. 
on the basis of preference rather than merit, the women consistently rated their performance more negatively, took less credit for successful outcomes, and were less eager to persist in their leadership roles; they also viewed themselves as more deficient in general leadership skills. $^{67}$

Women who were told that they had been selected on the basis of their ability rather than their gender had fewer process-created doubts concerning their self-worth. These findings indicate that universalistic procedures, which focus on an applicant's skills along with her race or gender in making a selection, are less likely than particularistic processes to cause the internal barriers to job opportunities that stem from self-doubt.

The researchers in this study quickly recognized the importance of these findings for employers who were shaping selection procedures:

This research has important implications for current personnel policies and practices. Although it is rare that competence is not at all a factor when affirmative action plans are in operation, the common perception is that it is not a major criterion for selection. Our results suggest that when this is the case, sex-based preferential selection can trigger a vicious cycle of negative self-regard for women targeted for favored treatment. Ironically, this may happen to a woman even when she truly is qualified for the position and would have been hired had merit been the sole basis of selection. . . . [T]he findings presented here . . . underscore the necessity of paying heed to the way in which such programs are implemented and, in particular, of making sure that selection without regard to competence is not believed to characterize affirmative action efforts. ${ }^{68}$

The consistent findings of these studies indicate that selection procedures which are perceived as relying solely on an applicant's gender (or by analogy, on an applicant's race) impose significant barriers to employment opportunities. Significantly, these barriers appear even when the beneficiaries of these supposed sex-based procedures were told that they had the necessary (or even superior) skills for the job. The studies reveal, however, that such perception-based barriers are much less likely to be imposed in cases where the applicants skills are also seen as an important factor in the selection. These findings provide a strong sociological foundation for the position put forward in this Note that courts should look to public and workers' perceptions in distinguishing between pass-fail and multicomponent procedures.

67. Id. at 66-67 (emphasis added).

68. Id. at 68 (emphasis added). The literature appears to be devoid of studies examining the psychological effects of selection procedures on racial minorities. 


\section{The "Perceptions Approach" and Employment PROCEDURES}

Given the impact of employment procedures on perceptions of the qualifications of minority and female workers, the distinction between pass-fail barriers and multicomponent selection techniques assumes a new level of importance. Although the number of minority or female applicants hired by an employer may be the same whether she uses a pass-fail or multicomponent approach, the identifiable sex- or race-based selection found in the former approach is far more likely to be perceived as unfair by applicants and the public at large. Additionally, a pass-fail barrier with a disparate impact results in a disproportionate number of minorities and women from the original applicant pool being told explicitly that they are unqualified. Even those minority and female applicants who do meet the quality standard are often ultimately selected through an affirmative action program where race or sex is seen as the main determinant for placement. Use of a pass-fail barrier, therefore, also fuels the social myth of racial or sexual superiority and undercuts the feelings of self-worth of even those minority and female applicants who have the skills needed to surmount the pass-fail barrier. ${ }^{6 \theta} \mathrm{A}$ universalistic multicomponent process, even one which makes an identical disparate determination at a particular stage, is much less likely to have such an effect. ${ }^{70}$ The only result the applicant can identify in a multicomponent approach is the end result, where minority and female applicants are selected at a rate equal to that of other applicants. This outward appearance does not give rise to perceptions of either inequity or inequality.

This analysis of the distinction between pass-fail barriers and multicomponent processes may be useful in resolving the circuit split that currently exists over the use of the bottom line defense. In Teal, the Supreme Court rejected selection procedures that "foster[] . . . stratified job environments to the disadvantage of minority citizens." "71 Pass-fail barriers foster stratified job environments in at least three ways that are less likely to arise from multicomponent processes. First, identifiable pass-fail barriers, especially those known to have a disparate impact disadvantaging minority or female job applicants (for example, culturally-biased standardized examinations or physical strength tests), may cause fewer minority and female candidates to apply for a given job. Second, these procedures can create self-doubt in the minds of those minority and female candidates who do apply, doubt which is likely to spill over into job performance and motivation. Third, pass-fail procedures impose an additional hurdle in job

69. See supra text accompanying notes 67-68.

70. See id.

71. Connecticut v. Teal, 457 U.S. 440, 456 (1982) (quoting McDonnell Douglas Corp. v. Green, 411 U.S. 792, 800 (1973)). 
advancement for minorities and women by creating the perception in other workers that these workers did not earn their jobs in the first place.

The courts, therefore, should continue to prohibit the bottom line defense where pass-fail barriers are used. Where an employer uses a multicomponent selection technique, however, the court's task will be somewhat more complex. Employers using a selection procedure generally perceived as reinforcing perceptions of white male superiority and basing ultimate bottom line selections on race or sex, rather than on a recognition of qualifications, should not be able to rely upon the bottom line defense, since such a process is likely to lead to the same barriers to opportunity as a pass-fail procedure. Where the technique is seen by both minority and majority workers as a selection based on universalistic concerns, however, equality of placement at the bottom line should be a defense against title VII claims.

A multicomponent procedure will be disfavored under this analysis to the degree to which a "merit" component with a disparate impact is distinct and identifiable as important and relevant to the job applicants. ${ }^{72} \mathrm{~A}$ pass-fail barrier with a disparate impact on minorities and women falls to one extreme in this analysis; it is a readily identifiable measure that purports to determine the overall ability of an applicant to perform a job adequately. A single exam question falls to the other extreme, since applicants will attribute to it little independent importance. Between these two extremes, the court will apply a flexible standard aimed at determining the effect of the procedure on applicants' perceptions. ${ }^{73}$

This analysis provides a theory by which the decisions in Burney and Brunet can be reconciled. In Burney, the court rejected a bottom line defense where a physical training program and physical performance examination had a disparate impact on female police cadets. The physical requirements generally did not constitute a pass-fail barrier, ${ }^{74}$ but were a distinct and important part of the selection process. Further, fellow cadets could easily observe and judge the performance of their contemporaries in the ten week physical training program. ${ }^{75}$ Indeed, instructors subjectively determined half of each cadet's score in this program by observation of physical performance during the ten weeks. ${ }^{78}$ From these facts, one can

72. The court will thus, in part, be pursuing a similar course to that adopted by the Second Circuit in Teal, supra text accompanying notes 22-24, except that the determining factor will be whether the "barrier" is easily "identifiable" to the job applicants rather than to the court.

73. Given the difficulty in predicting the impact on public perceptions of an infinite number of possible fact patterns, it would be inappropriate to predetermine a "bright-line" rule. Rather, as in the establishment clause cases, infra notes 88-89 and accompanying text, courts would have to use their discretion.

74. See supra note 39 and accompanying text.

75. Burney v. City of Pawtucket, 559 F. Supp. 1089, 1095-96 (D.R.I. 1983) (women given demerits when they could not keep pace with men in calisthenics), appeal dismissed, 728 F.2d 547 (1st Cir. 1984).

76. Id. at 1096. 
assume that the cadets were well aware of the male superiority in the physical skills measured in the examination. Unless this superiority was offset by an equally observable superiority by female cadets in another qualification, the effect of these programs on the perceptions of the police cadets would be similar to the effects of a program with a pass-fail barrier.

In Brunet, on the other hand, the contested selection components were individual subtests in an overall hiring test. All applicants went through the entire testing process with much less ability to identify the results of any one subtest. ${ }^{77}$ No one subtest was seen as having special importance. Thus, a court using the "appearances" approach might uphold the bottom line defense in this case, as did the Brunet court.

\section{A. Legal Support Under Title VII For the Perceptions Analysis}

While the language of title VII does not refer to public perceptions, procedures that encourage perceptions of inequality and discourage advancements by minorities and women clearly violate the purpose behind the statute. As the Griggs Court explained, "The objective of Congress in the enactment of Title VII . . . was to achieve equality of employment opportunities . . .."78 Title VII, the Court continued, prohibits "employment procedures or testing mechanisms that operate as "built-in headwinds' for minority groups."79 The sociological evidence presented above clearly demonstrates that pass-fail and similarly particularistic procedures with disparate impacts act as "built-in headwinds" by denying minority and female applicants the opportunity to "earn" a job. Increased perceptions of their inequality and decreased acceptance of affirmative action hinder minorities and women as groups in their efforts to achieve equal employment opportunity. The individual minority or female applicant is either rejected as unqualified or is "given" a job because of his or her under-privileged status.

As noted above, particularistic procedures are also likely to reduce the number of minority and female job applicants. In finding a violation of title VII in Dothard $v$. Rawlinson, ${ }^{80}$ the Supreme Court based its holding in large part on the fact that the selection process was such that "other-

77. Brunet v. City of Columbus, 642 F. Supp. 1214, 1224 (S.D. Ohio 1986), appeal dismissed, 826 F.2d 1062 (6th Cir. 1987), cert. denied, 108 S. Ct. 1593 (1988). Only one of the challenged components in Brunet, the physical component test, was readily observable by other applicants. A description of the procedure used in conducting this test in subsequent years, however, indicates that even here applicants had much less opportunity to determine the abilities of their fellow applicants than was available to the cadets in Burney. The job applicants in Brunet were separated into groups and took a short (five to ten minutes) physical test at ten minute intervals. Id. at 1231.

78. Griggs v. Duke Power Co., 401 U.S. 424, 429 (1971).

79. Id. at 432 (emphasis added).

80. 433 U.S. 321 (1977). 
wise qualified people might be discouraged from applying . . ."81 Particularistic procedures can also lead to internal (self-doubt) and external (lack of respect) barriers to job advancement. In Teal, the Supreme Court indicated that title VII prohibited such " 'artificial, arbitrary and unnecessary' employer-created barriers to professional development . . . ."82

\section{B. Perceptions as Ground for Legal Doctrine}

In Regents of the University of California v. Bakke, ${ }^{83}$ the Supreme Court suggested perception-based reasoning similar to that proposed in this Note. Justice Powell, announcing the judgment of a splintered Court, found an affirmative action plan of the medical school at the University of California at Davis to be unconstitutional. The medical school's plan set aside sixteen out of one hundred places in the entering class for disadvantaged minority applicants. In rejecting this plan, Powell emphasized that white applicants, "[n]o matter how strong their qualifications, quantitative and extracurricular, . . . are never afforded the chance to compete with applicants from the preferred groups for the special admission seats . . ."84 Justice Powell contrasted this program with a plan established by Harvard College in which race was counted as a "plus" in an individual's application. The Harvard plan, Powell argued, "treats each applicant as an individual. . . His qualifications would have been weighed fairly and competitively." 85

The distinction made by Justice Powell in Bakke is analogous to the distinction at issue in this Note. The Davis plan, by explicitly excluding individuals from consideration for admission for the sixteen set aside places, caused race to become a particularized barrier. The Harvard plan, by internalizing the racial consideration, utilized a multicomponent approach. Significantly, in response to Justice Brennan's argument that there was no "sensible" distinction between the two school plans, ${ }^{86}$ Justice Powell referred to the different effect that the two plans would have on public perceptions: "Petitioner's program will be viewed as inherently unfair by the public generally as well as by applicants for admissions to state universities. Fairness in individual competition for opportunities . . . is a widely cherished American ethic . . . . As Mr. Justice Frankfurter declared in another connection, '[j]ustice must satisfy the appearance of justice." "87 This distinction recognized by Powell in Bakke is the same

81. Id. at 330 .

82. 457 U.S. 440,451 (1982) (quoting Griggs, 401 U.S. at 431 ).

83. 438 U.S. 265 (1978).

84. Id. at 319 .

85. Id. at 318 .

86. Id. at 378 (Brennan, J., concurring in part, dissenting in part).

87. Id. at 319 n.53 (citation omitted) (emphasis added). At least one observer has supported Justice Powell's distinction on the basis of public perceptions: "In terms of the appearance of justice-more particularly, in terms of the potential for generating racial resentment-there is a signifi- 
distinction advocated by this Note for bottom line defense cases. Furthermore, Justice Powell's concern for the perceptions that the Davis Plan would generate indicates that the Court might be open to a similar perception-based argument in title VII disparate impact cases.

The Supreme Court has already shown the willingness and competence to measure the effects of perceptions of substantive law in the context of the establishment clause. In School District of City of Grand Rapids $v$. Ball, the Court held that

an important concern of the effects test [of the establishment clause] is whether the symbolic union of church and state effected by the challenged governmental action is sufficiently likely to be perceived by adherents of the controlling denominations as an endorsement, and by nonadherents as a disapproval, of their individual religious choices. $^{88}$

This past term, the Court again focused on the appearance of a government action: "The Establishment Clause, at the very least, prohibits government from appearing to take a position on questions of religious belief . . . ."88 These cases indicate that the perception-based analysis suggested in this Note is well within the scope of the Court's jurisprudence.

Beyond the practical question of the competence of the courts to apply the perception-based approach presented in this Note lie philosophical questions arising from the approach's premise. By relying primarily on outward appearances to shape public perceptions of affirmative action, the proposal arguably relies on deception to bolster policies that would otherwise be subject to strong opposition. The proposal thus seems to run afoul of some scholars' admonitions against judicial subterfuge. ${ }^{30}$

The "perceptions approach," however, is not in fact deceptive. By requiring employers to adopt more universalistic selection criteria, this Note does not require employers to gloss over controversy. Rather, it requires that employers approach their selection decisions in a manner that is more consistent with the concept of equality in our society. The bottom line defense would be available under the proposed theory, not where an em-

cant difference between a program like Davis's and one like Harvard's." Perry, Modern Equal Protection: A Conceptualization and Appraisal, 79 Colum. L. REv. 1023, 1049 (1979) (emphasis in original).

88. 473 U.S. 373,390 (1985) (emphasis added); see also Wallace v. Jaffree, 472 U.S. 38,76 (1985) (O'Connor, J., concurring) ("The relevant issue is whether an objective observer . . . would perceive [the statute] as a state endorsement of prayer in public schools."); Lynch v. Donnelly, 465 U.S. 668, 692 (1984) (O'Connor, J., concurring) (looking to effect of government practice "in reality or public perception").

89. County of Allegheny v. ACLU, 109 S. Ct. 3086, 3101 (1989) (emphasis added); see also Smith, Symbols, Perceptions, and Doctrinal Illusions; Establishment Neutrality and the "No Endorsement" Test, 86 Mich. L. REv. 266 (1987) (discussing role of perceptions in Court's analysis of establishment clause cases).

90. See, e.g., Gerwirtz, Remedies and Resistance, 92 YALE L.J. 585, 666-74 (1983). 
ployer has "hidden" the discrimination or inequity in her selection process, but rather where she has used a process that measures an applicant's ability in such a way that race or sex, as such, is no longer the determinative factor. ${ }^{91}$

\section{Conclusion}

In the years following the Supreme Court's rejection of the bottom line defense in Teal, lower courts have been unable to develop a coherent approach for evaluating the bottom line defense in the case of multicomponent selection processes. This Note argues that the courts might resolve this difficulty by inquiring into the psychological effects of different types of selection procedures in employment. Employment selection procedures not only determine an individual's chance to acquire a job or a promotion. They also help to shape the understanding with which workers and the rest of the public view affirmative action and equal employment opportunity.

Particularistic race- or sex-based selection procedures, like the one used in Teal, foster the perception that minorities and women are less qualified for positions and are selected solely on the basis of their underprivileged status. These perceptions impose barriers to job opportunities for minorities and women. Universalistic selection procedures, on the other hand, do not focus on an applicant's color or race but rely instead on a variety of measures, which may include diversity of backgrounds, social skills, work ethic, and scholastic skills, as well as affirmative action goals, in reaching their decisions. These procedures, therefore, place more of a focus on the qualifications of the applicants and are consequently less likely to foster the adverse perceptions that can impede opportunities for minority and female job applicants. By appreciating the relevance of selection procedures to public perceptions, courts can end the confusion that has resulted from Teal and limit the bottom line defense to those cases in which it does not defeat the underlying purpose of title VII, namely to free society from racial or sexual inequality in perception and in fact.

91. There are, admittedly, some positions, such as dock worker, where physical distinctions between the sexes are determinative. While universalistic approaches may be less realistic for these positions, the number of jobs that are solely based on physical strength is limited. 
